\title{
Applications of Re-Engineered Productivity Award Model in the Measurement of Water Supply System Performance in Nigeria
}

\author{
Okolie S. T. A. ${ }^{1}$, Onawumi A. S. ${ }^{2}$, Adio T. A. ${ }^{3}$ \\ ${ }^{1}$ Department of Mechanical Engineering, Covenant University, Ota. Ogun State, Nigeria. \\ ${ }^{2,3}$ Department ofMechanical Engineering Department, Ladoke Akintola University of Technology, Ogbomoso. Oyo State. \\ Nigeria.
}

\begin{abstract}
The purpose of this study is to measure performance and identify operational strategies for improving water supply systems in Nigeria. Water has remained the most crucial element in the environment as mankind significantly depends on it for their existence. Performance metrics framework for productivity of water supply system (WSS) in Nigeria has thus far been underestimated hence the need for user friendly approach to effectively assess critical activities of the system. A reengineered productivity award model (RPAM) adopted in this study consists of 10-point core measures that control overall performance of the WSS as well as other supportive measures for the realization of set goals of the system. The application of the model recorded a score of $44.08 \%$ which is an inducement to placing WSS on the threshold of significant achievement of strategic goals. This suggests possible adaptation of the model and improvement effort which has the capacity of addressing identified barriers to its implementation. The capacities of the strategic adaptive framework include creation of competitive platform for recognizing stakeholders who have greater influence in higher productivity solutions in water supply systems.
\end{abstract}

Keywords-Award Criteria,Modeling, Performance Measurement, Re-Engineered Productivity Award Model (RPAM), Water Supply System (WSS).

\section{INTRODUCTION}

The importance of water has been underscored by many authors and scholars. All studies agree that water has remained the most crucial element in the environment and that mankind has been so dependent on water (World's Water 2014). Given the scenario of abundance of water, this study considers Nigeria with a mean annual rain fall of $1400 \mathrm{~mm}$ and loss of $1,070 \mathrm{~mm}$ to evaporation leaving a leftover/surplus of $330 \mathrm{~mm}$ which by world's standard considered as a large water supply, but for what Peters (1993) describes as "Uneven distribution" it is grossly inadequate resulting from poor infrastructure. Minimizing the consequences of infrastructural decay and improving water distribution network resilience therefore become priorities in the water industry (Hyuanget al 2011). The prevailing problem of water generation and distribution is not delivering good quality water today, particularly to smaller communities, the physical facilities the states are maintaining and good strong programs, which are so vital for providing technical assistance and guidance to utilities (Tiemann 2003). Thus, need to develop models to mitigate the consequences. These models integrate search for constant assessment and measures to identify and provide solutions for improvement (Earl et al 2003).

Throughout the world, the essential water problem is how best to reconcile the increasing use of the fixed supply with the needs and constraints of human society, in a way that maintains stable environment (Biswas 1978). Comparative study of some African countries and urban Brazil in North America conclude that water suppliers are likely to have no effect, if no one cares about how it is used, stored and distributed (Prost 1986). This is a functional problem, which nobody has explicitly addressed (Ayoadeet al 2006). A few identified problems hindering adequate water supply in Nigeria include poor policy objective, level of service, manpower development and funding (Falusi and Gbadegesin1998). The water supply agencies in West Africa and Nigeria in particular are under pressures to evenly distribute water (West African Minister's Conference 1988). It becomes obvious that water supply agencies cannot generate and distribute from the abundant supply of rain and river water to satisfy the ever-increasing need for water supply. Infrastructural performance became very challenging. Water production facilities in Nigeria were rarely operated to capacity due to dilapidated and obsolescence infrastructure including power supply (World Bank 2010, Ajisegiri, 2011). The operating cost of water supply by existing agencies increased by the need to rely on diesel generators or having to build own power plants, poor maintenance of water supply facilities, leading to intermittent supply and high levels of non-revenue. As of 2000, according to World Bank, about 80 percent of government owned 
water supply systems in small towns were non-functional (World Bank/FRN, 2012). However, investments and capacity building for communities to enhance the functionality of water points can be increased in the shortterm. Further studies according to USAID 2007, water supply system agencies are massively overstaffed. In 2000, there was about 70 staff to 1000 customers compared to a best practice ratio of 3:5 (World Bank 2000). Non-water revenue often exceeds 50 percent (USAID 2007). The tariff revenue covers only 2 percent of costs of supplying water. Consequent to this daunting challenge the water supply agency under study commissioned the study of its water supply systems with a view to assess performance efficiency and identify strategies of optimizing performance using ReEngineered Productivity Award Model (RPAM) Criteria. The overall intension of the agency was to perform optimally and be referenced as Productive Agency (Edosonwan 1991). Other reasons were to create a greater awareness and ownership amongst stakeholders of the agency. There are similar award models in the literature, this include Malcolm Bald Ridge, National Quality Award of 1987, EFQM Award Model of 2012, Sirilanka National Productivity Award 2015, etc. The award models have similar goals, but varying award criteria that is dependent on economic realities and agenda of the nation using the model (Emanet, 2007). The awards promote awareness of performance excellence as an increasingly important element in competitiveness (Riemann 1987). In using the RPAM in the assessment of its performance, it would encourage the stakeholders come forward with good productivity ideas and solutions. Stakeholder's loyalty being critical to optimal performance has huge influence in adapting high productivity solutions. It promotes the sharing of successful performance strategies and the benefits derived using these strategies. Aiming at winning the award or being high productive agency would enable the different individuals and departments to be better recognized and rewarded too (Bowyer 1991). The use of award criteria would therefore, evolve strategies that would monitor measure and evaluate the performance of the supply agencies for continuous improvement. $65 \%$ of hospitals are likely to use the Bald ridge criteria for performance excellence as an internal tool by 2018 (Hertz 2010).

The present study presents a performance measurement framework that would enable water supply agencies build a cognitive thinking capacity and create new knowledge to facilitate the successful use of the framework to become an excellent productive agency worthy of earning a national award of honor. Median growth in revenue for two-time Bald ridge award winners is $92 \%$ according to Bald ridge program impact report 2015. The model provides opportunities for users to lean and deploy the associated award criteria and to perform an initial assessment of trial organization (Shahin et al, 2012). This study further discusses the productivity award model, its development, application and as do it your-self-model for performance measurement.

\section{PRODUCTIVITY AWARD MODEL}

The productivity award model was aimed at putting the water supply agency on the threshold of true excellent productive agency. It has the objective of fostering the concept of continuous productivity improvement and use of the award criteria to improve water supply system, and measure its performance. It also helps organizations assess their improvement efforts, diagnose their overall performance management system and identify their strengths and opportunities for improvement and identify award recipients that will serve as role models for other organizations (Bald ridge Award Model 2010). The framework utilized the concept of RPAM criteria. The ten point criteria are shown in table 1 , with maximum score points to each criterion. The total maximum score is 1000 points. The 10 - point criteria is divided into four groups. The groups are classified as Driver, System, and Maintenance of performance and Goals. Figure 1 shows the groups and demonstrating the interdependency of the criteria chosen for the RPAM. The figure also depicts the symbolic relationship and further explains the model. Each of the groups leads to the other. It succinctly shows that all criteria must work together to produce result that is reflective of the actual performance.

\section{MATERIALS AND METHODS}

A re-designed NPOM award criterion was utilized in developing an award model for water distribution system in Nigeria. The award model had 10 interdependent criteria that were viewed as core measures that are reflective of the true performance measure. The redesigned criteria are slightly different from the criteria presently in use in Nigeria to select the awardees. The redesign and method of selection aim at reducing the subjective approach inherent in the present. The divisions and subdivisions of the categories are designed to illicit sufficient information of the true position of the water supply system of the study. The model considered ten criteria against nine criteria presently in use. Table1 shows the criteria and their definitions. The inclusion of the tenth criteria leadership was on the bases that reasons for failure and non-performance of businesses are always ascribed to lack of leadership and understanding according to Bowyer (1991). Leadership is the driving force that provides enabling environment, brings resources and makes things happen. The total score 
available is 1000 points as shown in table 1. Each criterion is divided into five categories bringing the total to 50 different items. Each of the items in a category is further sub-divided into smaller items/questions as to bring out measurable quantities. This implies that each of the 5 categories has two quantifiable questions to each.
The performances are scores from these questions. Table 2 presents the template designed for obtaining the scores based on measurable quantities and answers to questions pertaining to the system of study.

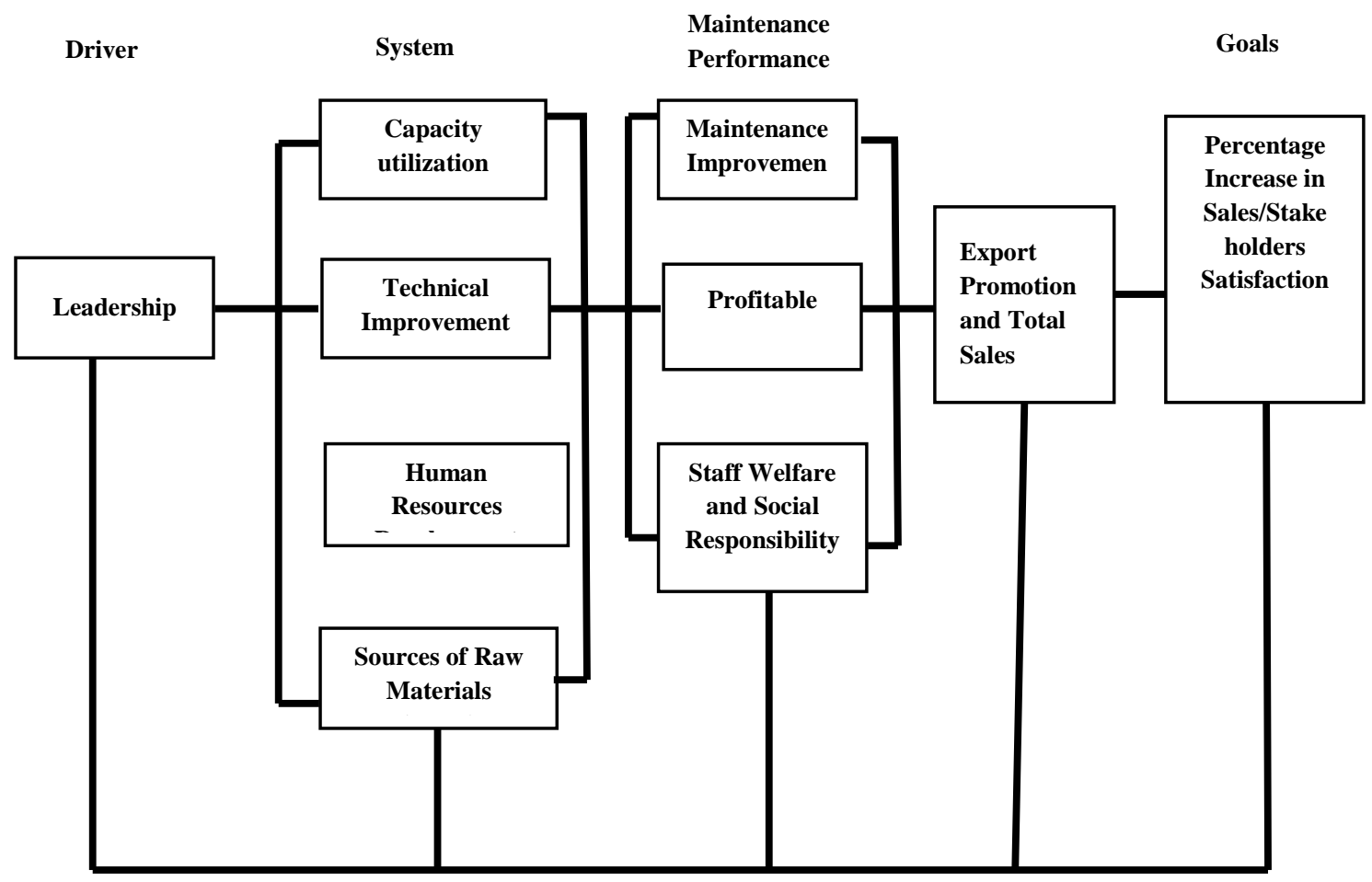

Fig. 1: Re Designed Criterion Depicting the Interdependency of the Criteria Categories (10-point Criteria) (Baldridge Award Model 2010).

Table.1: 10 point criterial, definitions and maximum scores

\begin{tabular}{|l|l|l|c|}
\hline & CRITERIA & MEASURE/MAXIMUM & $\begin{array}{c}\text { MAXIMUM } \\
\text { SCORES }\end{array}$ \\
\hline 1 & Sales turnover & Percentage Increase in Sale & 100 \\
\hline 3 & Export Promotion & $\begin{array}{l}\text { Values of Exports over value of sales } \\
\text { made }\end{array}$ & 50 \\
\hline 4 & Profitability & $\begin{array}{l}\text { Maintenance cost over total operating } \\
\text { cost }\end{array}$ & 200 \\
\hline 5 & $\begin{array}{l}\text { Staff welfare and social } \\
\text { responsibility }\end{array}$ & $\begin{array}{l}\text { Net profit over paid up capital amount spent on safety, staff } \\
\text { welfare and community efforts etc. }\end{array}$ & 100 \\
\hline 6 & Capacity utilization & $\begin{array}{l}\text { Operating capacity over installed } \\
\text { capacity }\end{array}$ & 100 \\
\hline 7 & Technical improvement & $\begin{array}{l}\text { Value of new methods over total cost } \\
\text { of production }\end{array}$ & 50 \\
\hline 8 & Human resources development & $\begin{array}{l}\text { Training, employment creation } \\
\text { potentials }\end{array}$ & 100 \\
\hline 9 & Sourcing of Row material & $\begin{array}{l}\text { Local raw material used over total raw } \\
\text { material used }\end{array}$ & 100 \\
\hline 10 & Leadership & Result oriented organization & $\mathbf{1 0 0 0}$ Points \\
\hline & TOTAL & &
\end{tabular}


Table.2: Score Template

\begin{tabular}{|c|c|c|c|}
\hline Criteria & Items & Questions & $\begin{array}{l}\text { Maximum } \\
\text { Scores }\end{array}$ \\
\hline \multirow[t]{5}{*}{$\begin{array}{l}\text { Technical } \\
\text { Improvement }\end{array}$} & i. Work Study & $\begin{array}{l}\text { Do you have performance standards? } \\
\text { What are the standards used for? } \\
\text { Do you have work study department? } \\
\text { If you have, does it have authority to effect change }\end{array}$ & 10 \\
\hline & $\begin{array}{l}\text { ii. Value added/ product } \\
\text { cost }\end{array}$ & $\begin{array}{l}\text { Are there inputs that were originally added that is } \\
\text { not available due to scarcity? } \\
\text { What effect does it have on production? } \\
\text { What percentage value added to your end } \\
\text { product? }\end{array}$ & 10 \\
\hline & $\begin{array}{l}\text { iii. Research } \\
\text { Studies }\end{array}$ & $\begin{array}{l}\text { How many ongoing research studies or product do } \\
\text { you have? } \\
\text { How many completed in the year? }\end{array}$ & 10 \\
\hline & $\begin{array}{l}\text { iv. Stakeholders/ } \\
\text { consumers } \\
\text { protection }\end{array}$ & $\begin{array}{l}\text { How many water-borne diseases reported to you } \\
\text { in a year? } \\
\text { Are you competitive }\end{array}$ & 10 \\
\hline & $\begin{array}{l}\text { v. Product } \\
\text { Advertisement }\end{array}$ & $\begin{array}{l}\text { Do you issue warning if need be? } \\
\text { How often do you advertise }\end{array}$ & 10 \\
\hline
\end{tabular}

The services of 5 productivity assessors were utilized in the measurement exercise; self-assessment short course was given to the assessors after studying extensively the operations of the water supply agency. A questionnaire for each category was developed and total number of 100 questions was administered for the 10 categories as shown in table 3. A score of 0 to 5 is assignable to each category, aggregate scores were obtained and average of the assessors scores were used as actual score to each criterion.

\section{RESULTS AND DISCURSIONS}

The summary of scores of the productivity assessors on the performance of water supply system based on the 10 point criteria is presented on table 3 . The assessment showed a score of 440.8 points out 1000 points, representing only $44.08 \%$ as an inducement to putting the water supply agency on a threshold of a productive Agency. However, a score of 59.2 points out of 200 points or $20.6 \%$ for maintenance, 14.7 points out of 50 points or $29.4 \%$, technical improvement, human resources development 32.4 scores out 100 points or $32.4 \%$ and 21.6 points out of 100 points or $21.6 \%$ are indeed pointing to areas of improvement. The results to a degree of measurement agrees with (USAID 2007), (Benson 2011) and (Peng et al 2009), that summarizes that sustainable utilization of water resources management measures should have to be put in use such as high water use efficiency, maintenance, and protection of water supply systems as well as increasing.

Table.3: Assessment of the Water Supply System (WSS)

\begin{tabular}{|c|c|c|c|c|}
\hline S/No. & Criteria & $\begin{array}{l}\text { Maximum } \\
\text { Points } \\
\text { Research } \\
\text { officer }\end{array}$ & $\begin{array}{l}\text { Average Score } \\
\text { point of the five } \\
\text { point Research } \\
\text { officer }\end{array}$ & $\begin{array}{l}\text { Total } \\
\text { Average } \\
\text { point } \\
\text { scored }\end{array}$ \\
\hline 1 & $\begin{array}{l}\text { Profitability } \\
\text { i. Input/output ratio } \\
\text { ii. Revenue generated } \\
\text { iii. Selling price/ unit } \\
\text { iv. Cost price/unit } \\
\text { v. Quality result }\end{array}$ & 100 & $\begin{array}{r}5.4 \\
2.6 \\
4.2 \\
2.0 \\
12.9\end{array}$ & 26.2 \\
\hline 2 & $\begin{array}{l}\text { Local Raw Material Sources } \\
\text { i. Location/Proximate } \\
\text { ii. Quality } \\
\text { iii. Quantity/Availability }\end{array}$ & 100 & $\begin{array}{l}19.0 \\
15.8 \\
10.0\end{array}$ & 75.6 \\
\hline
\end{tabular}




\begin{tabular}{|c|c|c|c|c|}
\hline & $\begin{array}{l}\text { iv. Research Effort } \\
\begin{array}{l}\text { v. Infrastructural development to host } \\
\text { community }\end{array} \\
\end{array}$ & & $\begin{array}{l}10.8 \\
10.0\end{array}$ & \\
\hline 3 & $\begin{array}{l}\text { Maintenance } \\
\text { i. Fund Maintenance Policy } \\
\text { ii. Preventive maintenance } \\
\text { iii. Breakdown Maintenance } \\
\text { iv. Maintenance Cost } \\
\text { v. Operating Maintenance }\end{array}$ & 200 & $\begin{array}{l}25.6 \\
15.6 \\
12.0 \\
10.6 \\
14.0\end{array}$ & 77.8 \\
\hline 4 & $\begin{array}{l}\text { Technical Improvement } \\
\text { i. Method study/Task related techniques } \\
\text { ii. Value added } \\
\text { iii. Research/Study } \\
\text { iv. Stakeholders Protection } \\
\text { v. Product Advertisement }\end{array}$ & 50 & $\begin{array}{l}4.0 \\
3.6 \\
3.6 \\
3.6 \\
3.0\end{array}$ & 17.0 \\
\hline 5 & $\begin{array}{l}\text { Export Promotion } \\
\text { i. Standard Org. Cert. } \\
\text { ii. Int'l Standard organization (ISO) Certificate } \\
\text { iii. Acceptability/Stakeholders } \\
\text { iv. Volume of export/regularity } \\
\text { v. NAFDAC certificate }\end{array}$ & 50 & $\begin{array}{l}2.2 \\
0.0 \\
6.0 \\
0.0 \\
8.0\end{array}$ & 16.2 \\
\hline 6 & $\begin{array}{l}\text { Human Res. Dev. } \\
\text { i. Professional staff skills/unskilled } \\
\text { ii. Labour Ratio } \\
\text { iii. No. of Staff } \\
\text { iv. Trained Local Number of staff trained } \\
\text { overseas } \\
\text { v. Exchange studies }\end{array}$ & 100 & $\begin{array}{r}15.0 \\
12.0 \\
10.4 \\
0.6 \\
0.0\end{array}$ & 38.0 \\
\hline 7 & $\begin{array}{l}\text { Staff Welfare } \\
\text { i. Health Care } \\
\text { ii. Workman's compensation } \\
\text { iii. Canteen service } \\
\text { iv. Housing Scheme } \\
\end{array}$ & 100 & $\begin{array}{r}14.0 \\
16.2 \\
8.0 \\
9.0\end{array}$ & 47.2 \\
\hline 8 & $\begin{array}{l}\text { Sale/Turnover Growth } \\
\text { i. Stakeholders satisfaction } \\
\text { ii. Quality product/Service } \\
\text { iii. Volume of Sales } \\
\text { iv. Competitiveness/Advert } \\
\text { v. Availability }\end{array}$ & 100 & $\begin{array}{l}11.4 \\
9.6 \\
8.8 \\
9.8 \\
2.8\end{array}$ & 41.8 \\
\hline 9 & $\begin{array}{l}\text { Capacity Utilization } \\
\text { i. Installed/Operating Capacity } \\
\text { ii. Utilization program. } \\
\text { iii. Product diversification } \\
\text { iv. Employment level } \\
\text { v. Machine availability }\end{array}$ & 130 & $\begin{array}{c}13.8 \\
7.0 \\
0.6 \\
21.0 \\
17.0\end{array}$ & 53.8 \\
\hline 10 & $\begin{array}{l}\text { Leadership } \\
\text { i. Management/Worker relationship } \\
\text { ii. Commitment to leadership } \\
\text { iii. Leadership in providing resources } \\
\text { iv. Leadership role/result } \\
\text { v. Leadership satisfaction comparison }\end{array}$ & 70 & $\begin{array}{c}10.8 \\
8.6 \\
7.6 \\
6.0 \\
8.6\end{array}$ & 41.6 \\
\hline & Total Scored Points & 1000 & & 440.8 \\
\hline
\end{tabular}


Nigeria water supply system investment from the present 0.1billion USD to 2.6 billion USD annually. Figure 2shows graphically the percentage performance against maximum scores provided for each criteria of the assessment.

The use of RPAM criteria framework both in selection criteria and in method adapted in calculating the scores and result of the study reduced to a significant level the subjective tendency inherent in similar methods. The study commissioned 5 productivity assessors, who took the task of studying the award criteria and applied it in selfless assessment of the water supply system. The result is presented in Table 3 . The total score of 440.8 points out of 1000 points available was recorded in the assessment. This score represents $44.08 \%$. The highest score was raw material sourcing followed by maintenance and capacity utilization. A score of $80 \%$ is a benchmark for winning the prestigious award and an organization to be referred to as productive organization. The assessment criteria and method of application however, provided useful and valuable diagnosis of the problems associated with water supply systems of the agency of study. When the score was communicated to the management, the management recognized the score as immaterial; it reminds it that it has work to do. The study, however, revealed that the implementation of the measurement model requires a well- trained productivity assessors, industrial engineers working in conjunction with agencies' staff. The award framework is designed as a decision support system for management and requires managers to use the model for personal assessment at regular periods. However, as any change agent barriers to the use of the model may be inevitable. A poorly organized department may fear the outcome of the measurement process and may try to block the use of the model. Even the management of the model may be discouraged because of funds to support the modeling. The major barrier in implementing the model and measuring system may be in the requirement of detailed cost data. Modeling system is simplification of reality. The more detailed the model the closer the results will stimulate reality. Realization of the primary objective of the study is commendable and to know the agency's productivity status as well as areas of improvement.

With continuing advances for optimal supply and even distribution of water at minimum cost and quest for increased productivity, the Award framework would become better and be able to meet these needs. It is therefore, expected that the use of the model will become popular as the government confer this prestigious award of excellence to deserving organizations in Nigeria.

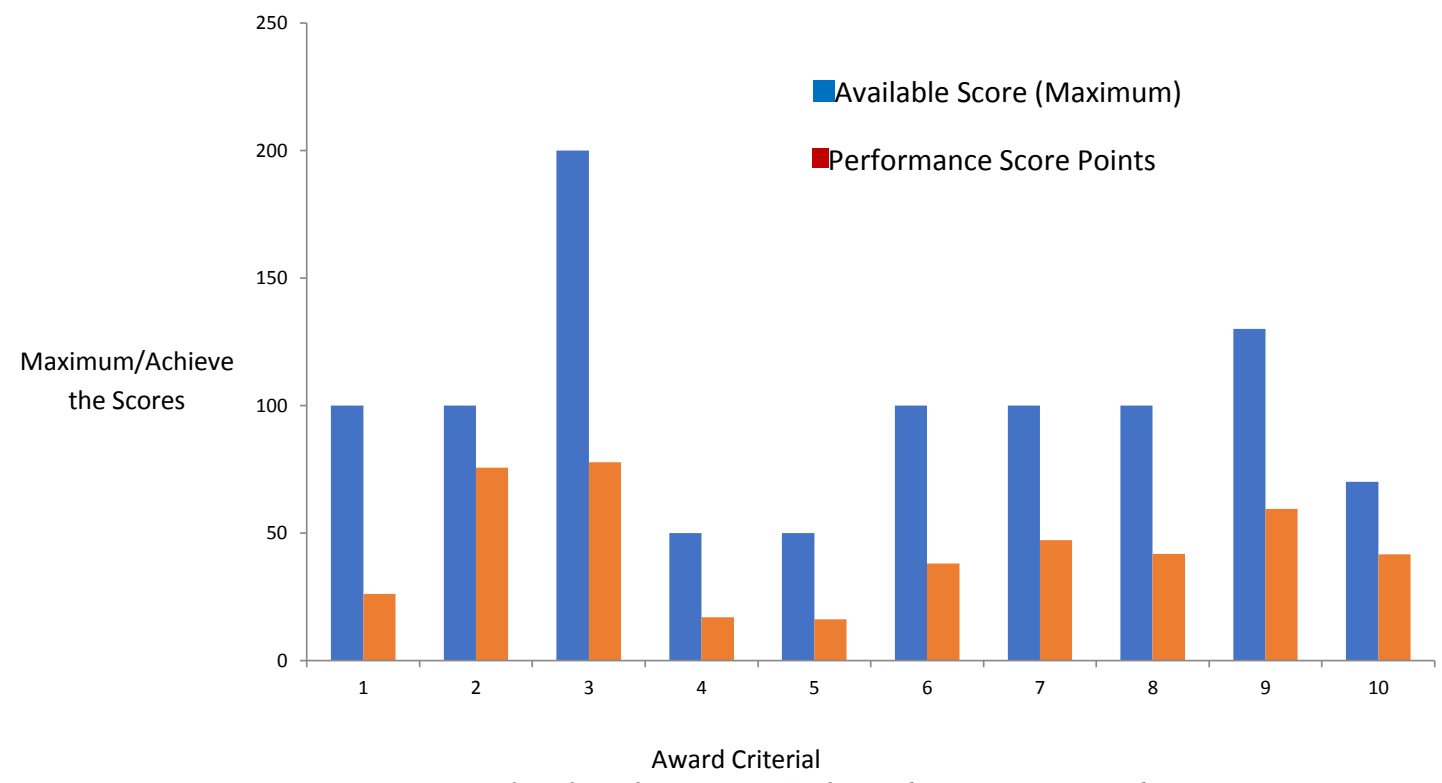

Fig.2: Plot of maximum/achieved scores vs award criteria

\section{CONCLUSION}

The study shows that the use of Award Model provided greater awareness and ownership amongst stakeholders. The use of the Award Criteria in developing the model stimulated improvement. Regardless of the score lines, the WSS realized it has work to do as strengths, opportunities and weaknesses were clearly identified. The study revealed that the award criteria were interdependent and for the Agency to be a productive agency the criteria must all work together. The performance framework designed as a decision support system for management requires managers to use the model for personal assessment at regular periods. The framework promotes the sharing of successful performance strategies and benefits derived using these strategies. 


\section{REFERENCES}

[1] The World's."Water, Information on the World's Water Fresh Resources.” Pacific Institute. 2014, vol. 8 ,

[2] H. G. Peters, "Water and Conflict." Fresh Water Resources and International Security," vol. 18, No. 1, pp $79-112.1993$.

[3] L. Y. Hyuang,Y. C. Wang, C.M. Liu,T. N. Wu,C. H. Chou, and F. C. Sung, "Water Outage Increases the Risk of Gastroenteritis and Eyes and Skin Diseases.” BMC Public Health 11:726.2011.

[4] M. Tiemann, "Safe Drinking Water Act: Implementation and Issues." CRS Issus Brief for Congress Reviewed through the CRS web. Order Code IB 10118. 2003.

[5] E. L. Earl,W. A. Wallace,D. M. Mendonca,J. E. Mitchell and J. H. Chow. "Managing Disruptions to Critical Infrastructure Interdependencies in the Context of the World Trade Center Attack", Beyond September 11th: Post-Disaster Research, University of Colorado, Boulder, CO. 2003, pp 165-198.

[6] M. R. Biswas, "Habitat in Retrospect." International Journal for Environmental Studies, vol II, 267-279. 1978.

[7] A. Prost, "The burden of blindness in Adult males in the Savanna villages of west Africa exposed to onchocercissis," Trans. Of the Royal Soc of Trip. Med. And Hygiene. 80.525-527.1986.

[8] A. A. AyoadeS. O.Fagade and A. A. Adebisi, "Dynamics of Limnological features of two manmade lakes in relation to fish production,"African J. Biotechnol.vol. 5. Issue 10, pp. 1013 - 1021. 2006.

[9] World Bank. "New Project to Bring Clean Water to 50.000 Households," 22 April, 2010

[10] A. O. Falusi, and A. Gbadegesin "Dependency and Subsidy in the Provision of Water for Domestic Agricultural and Industrial uses: Implications for Sustainable Development and Quality of Life”.1998.

[11] West African Ministers."Conference Integrated Water Resources Management”, Quagadongu. 1988.

[12] World Bank/Federal Republic of Nigeria. "Water supply and Sanitation Interim Strategy Note, Nov 2000, retrieval on April 11, 2012

[13]B. Ajisegiri, "National Project Coordinator of the World Bank-Assisted National Urban 1Water Sector Reform Project: Nigeria infrastructure," Daily Times, 28 March, 2011.

[14] USAID."Nigeria Water Sanitation profile," Ca. 2007.

[15] J. A. Edosonwan, "Baldridge Award: Focus on Customer Satisfaction," Industrial Engineering Proceedings.1991.
[16]C. Reimann, “Quality program” National Institute of Standards and Technology, Baldridge National Quality program. 1987.

[17]W. S. Bowyer, "Changing the Culture-Measuring the Progress," Royal Society of Chemistry. Sept,(1991).

[18] A. Shahin, H. R. Dolatabadi, and M. Kouchekian, "Proposing an integrated model of BSC and EFQM and analysing its influence on organizational strategies and performance: The case of isfahan municipality complex."International Journal of Academic Research in Economics and Management Sciences,vol. 1, issue 3, pp. 41-57. 2012.

[19]H. Emanet, "A Case Study on the Self-assessment in the Public Sector using the EFQM Excellence Model,'Cumhuriyet University Journal of Economy and Administrative Science, vol. 1, pp. 67-95. 2007.

[20]Baldrige Performance Excellence Program,"Validated Around the World," National Institute of Standards and Technology, July 6, 2010,

[21]H. Hertz,"Baldrige Performance Excellence Program, National Institute of Standards and Technology, "Leading at the "Leading Edge of Validated Management Practice," Insights of the Road to Excellence, July 2010. 